\title{
Comparing ERA-Interim clouds with satellite observations using a simplified satellite simulator
}

\author{
Martin Stengel $^{1}$, Cornelia Schlundt ${ }^{1}$, Stefan Stapelberg ${ }^{1}$, Oliver Sus $^{1,2}$, Salomon Eliasson $^{3}$, Ulrika Willén ${ }^{3}$, and \\ Jan Fokke Meirink ${ }^{4}$ \\ ${ }^{1}$ Deutscher Wetterdienst, Offenbach, Germany \\ ${ }^{2}$ European Organisation for the Exploitation of Meteorological Satellites, Darmstadt, Germany \\ ${ }^{3}$ Swedish Meteorological and Hydrological Institute, Norrköping, Sweden \\ ${ }^{4}$ Royal Netherlands Meteorological Institute (KNMI), De Bilt, the Netherlands
}

Correspondence: Martin Stengel (martin.stengel@dwd.de)

Received: 11 March 2018 - Discussion started: 30 May 2018

Revised: 12 November 2018 - Accepted: 13 November 2018 - Published: 12 December 2018

\begin{abstract}
An evaluation of the ERA-Interim clouds using satellite observations is presented. To facilitate such an evaluation in a proper way, a simplified satellite simulator has been developed and applied to 6-hourly ERA-Interim reanalysis data covering the period of 1982 to 2014 . The simulator converts modelled cloud fields, for example those of the ERAInterim reanalysis, to simulated cloud fields by accounting for specific characteristics of passive imaging satellite sensors such as the Advanced Very High Resolution Radiometer (AVHRR), which form the basis of many long-term observational datasets of cloud properties. It is attempted to keep the simulated cloud fields close to the original modelled cloud fields to allow a quality assessment of the latter based on comparisons of the simulated clouds fields with the observations.
\end{abstract}

Applying the simulator to ERA-Interim data, this study firstly focuses on the spatial distribution and frequency of clouds (total cloud fraction) and on their vertical position, using cloud-top pressure to express the cloud fraction of high-level, mid-level and low-level clouds. Furthermore, the cloud-top thermodynamic phase is investigated. All comparisons incorporate knowledge of systematic uncertainties in the satellite observations and are further stratified by accounting for the limited sensitivity of the observations to clouds with very low cloud optical thickness (COT).

The comparisons show that ERA-Interim cloud fraction is generally too low nearly everywhere on the globe except in the polar regions. This underestimation is caused by a lack of mid-level and/or low-level clouds, for which the comparisons only show a minor sensitivity to the cloud optical thickness thresholds applied. The amount of ERA-Interim high-level clouds, being higher than in the observations, agrees with the observations within their estimated uncertainties. Removing the optically very thin clouds $(\mathrm{COT}<0.15)$ from the model fields improves the agreement with the observations for highlevel cloud fraction locally (e.g. in the tropics), while for the mid-latitude regions, the best agreement for high-level cloud fraction is found when removing all clouds with COT $<1.0$. Comparisons of the cloud thermodynamic phase at the cloud top reveal a too high relative ice cloud frequency in ERAInterim, being most pronounced in the higher latitudes. Indications are found that this is due to the suppression of liquid cloud occurrence for temperatures below $-23{ }^{\circ} \mathrm{C}$ in ERAInterim.

The application of this simulator facilitates a more effective use of passive satellite observations of clouds in the evaluation of modelled cloudiness, for example in reanalyses.

\section{Introduction}

In the last 2 decades major progress has been achieved in improving the representation of clouds in regional and global atmospheric models. Nevertheless, clouds are still one of the largest uncertainties in estimating and interpreting the changes of the Earth's energy budget (Boucher et al., 2013). One of the main problems is that many atmospheric processes cannot be resolved by the current models, which op- 
erate on spatial scales ranging from tens to hundreds of kilometres. The small-scale processes related to clouds (e.g. cloud formation and glaciation) are implemented by means of parametrizations that connect grid box mean variables to sub-grid processes. Imperfect parametrizations of clouds will have a significant impact on other model variables and, hence, on the modelled climate sensitivity, which contributes to the large spread among present-day climate models in this respect (Dufresne and Bony, 2008). Thus, it is evident that cloud modelling needs to be carefully evaluated and improved to increase our confidence in atmospheric model results. One way to further enhance our understanding of cloud processes is to use high-resolution models (cloud-resolving models, CRMs). They are important tools for testing and improving the parametrizations of cloud-controlling processes, such as cumulus convection, turbulent mixing and aerosolcloud interaction (Boucher et al., 2013). However, global and long-term simulations are not feasible with CRMs due to computational cost.

Besides climate general circulation models (GCMs), present-day numerical weather prediction (NWP) models also rely on parametrizations to describe sub-grid cloud processes. NWP models are also used to generate reanalyses as ,for example, the Modern-Era Retrospective Analysis for Research and Applications, Version 2 (MERRA-2; Gelaro et al., 2017) and ERA-Interim (Dee et al., 2011). As reanalyses are on the one hand closely tied to observations through data assimilation cycles, they can be considered to represent the atmospheric state of the past decades very accurately. On the other hand, discontinuities in assimilated observation systems can create inhomogeneities in reanalysis data, which particularly need to be paid attention to in trend studies. Another inherent shortcoming of reanalyses such as MERRA-2 and ERA-Interim is that cloud properties are still exclusively modelled, due to difficulties in assimilating cloud-affected satellite radiances or properly assimilating the cloud properties themselves. The parametrizations in NWP are similar if not identical to the ones used in GCMs. Even though reasonable parameterizations have been developed, it remains challenging to balance the system regarding simplicity, realism, computational stability and efficiency in NWP, reanalysis and GCMs.

Indispensable for establishing or increasing confidence in atmospheric modelling, is the evaluation of the modelled cloud fields using observations. Satellite measurements are the only source for facilitating this on global scales, and corresponding model evaluations using satellite-based datasets have been done in the past, for example, for columnarintegrated water path (e.g. Waliser et al., 2009; Eliasson et al., 2011), cloud fraction (e.g. Dai et al., 2006; Sun et al., 2015) and cloud-top phase (e.g. Cesana et al., 2012; Weidle and Wernli, 2008). Using the standard output fields of models, these studies have already helped evaluating models as well as evaluating long-term monitoring of cloudiness, which is also in consideration of alternative observation sys- tems. However, for most cloud properties such evaluations often remain difficult due to significant differences in the representativeness of modelled clouds compared to clouds obtained from satellite observations. These differences are most significant in horizontal and vertical resolution and temporal sampling as well as deviating definitions of some geophysical quantities. While model horizontal resolutions could theoretically match those of satellite observations if enough computational power would be available, with current and past satellite missions at hand, it is not feasible to describe the complete three-dimensional atmospheric state at high temporal resolution with high accuracy and, at the same time, cover multiple decades.

Satellite retrievals use the measured intensity of radiation from a particular area and direction at a particular wavelength and infer cloud properties by solving an inverse problem. This implies that several assumptions and ancillary data are required in the forward modelling, causing limitations in deriving the geophysical quantities. In addition, passive spaceborne instruments usually observe only the top layer of a cloud, while active sensors are able to resolve a cloud vertically to some extent, though at the expense of a coarse spatial and temporal global coverage. Consequently, it is plausible that a direct comparison of modelled with observed clouds is suboptimal without building a bridge between the two data sources.

So-called satellite simulators give the opportunity to reduce this problem. They aim for simulating space-borne observations from model fields, which can comprise simulating both derived geophysical properties as well as observed raw measurements. For the remaining part of the paper the focus lies on simulating derived geophysical properties (pseudoretrievals). Figure 1 shows the general concept of such a simulator, which basically covers three steps: (1) the adjustment of spatial resolution, observation coverage and frequency (thus, the model fields are downscaled and sampled according to the characteristics of the satellite observations); (2) a pseudo-retrieval applied to un-averaged model fields mimicking an actual satellite retrieval also accounting for specific limitations; and (3) the statistical aggregation to daily or monthly properties (which is ideally done in the same way as for the observational datasets). The inputs to a simulator are usually grid box mean profiles (cloud fraction, cloud water content, temperature, etc.) and surface parameters (surface geopotential, land-sea mask, skin temperature, etc.).

The era of satellite simulators for evaluating climate model clouds began with the ISCCP (International Satellite Cloud Climatology Project) software package in 1999 (Klein and Jakob, 1999). The ISCCP dataset (Rossow and Schiffer, 1999) along with its corresponding simulator have been used in various studies that diagnosed the performance of GCMs. They have shown that common climate models at that time underestimated the total cloud cover, overestimated the frequency of optically thick clouds and underestimated the frequency of mid-level clouds (Kay et al., 2012). Since 
then, many other simulators for cloud-related instruments followed (e.g. Pincus et al., 2012), contributing to further improvements in cloud parameterizations in GCMs. A widely used tool for interfacing models with satellite observations is COSP (CFMIP Observation Simulator Package), which has been developed by the Cloud Feedback Model Intercomparison Project (CFMIP) community (Bodas-Salcedo et al., 2011). COSP provides the framework for simulating observations and datasets of multiple active and passive satellite instruments (e.g. CloudSat, CALIPSO, ISCCP, MISR, MODIS) and therefore facilitates an apple-to-apple evaluation of clouds, humidity and precipitation processes in diverse numerical models. However, many simulators include complex procedures such as radiative transfer simulations. Most of these procedures can be justified when aiming at performing synthetic satellite retrievals. The caveat of this approach is that so many modifications to the initial model fields are applied that any comparison to observations will be very difficult to interpret. For example, comparisons between simulated and observed COT should give insights in the accuracy of the COT of the modelled cloud fields.

In this study we follow a more conservative approach. We evaluate modelled clouds in ERA-Interim by employing a simplified satellite simulator, which can also be seen as a light version of a simulator that keeps the modifications to the model fields to a minimum. The simplified simulator uses precalculated and stored three-dimensional instantaneous model fields and accounts firstly for the relatively coarse spatial resolution of the model compared to observations and secondly for the limitations in the observations in terms of resolving subpixel and vertical cloud structures. Cloud variables that are not standard output in the model fields are determined following parametrizations used in the model if available. After undergoing these simplified simulations, ERA-Interim cloud fields are compared to cloud property observations of the Cloud_cci AVHRR-PM v2.0 dataset (Stengel et al., 2017a) with a focus on systematic climatological deviations between the two sources in the period of 1982-2014. Cloud properties addressed are total cloud fraction, the vertical placement of the clouds and the cloudtop thermodynamic phase. These properties have been selected due to the high confidence in them in the observational dataset and because of the availability of quantifying corresponding systematic uncertainties in the Cloud_cci AVHRRPM dataset by comparison to the Cloud-Aerosol Lidar with Orthogonal Polarization (CALIOP, Winker et al., 2009) instrument.

Acknowledging specific weather feature studies, e.g. studying the cloud structure in extratropical storms in Hawcroft et al. (2017), the application of a satellite simulator to reanalysis data for the global and long-term evaluation of modelled cloud properties has to our knowledge not been published in the peer-reviewed literature yet. Thus, the presented study adds novel aspects to the evaluation of ERA-
Interim cloud data, which has generally been very limited so far.

In this article we will firstly describe the Cloud_cci and ERA-Interim data used in our study (Sect. 2), followed by a detailed description of the simplified satellite simulator and a discussion of its output (Sect. 3). Selected comparisons of cloud fraction, cloud vertical placement and cloud phase are shown and discussed in Sect. 4. Section 5 summarizes and concludes the study.

\section{Datasets}

\subsection{The Cloud_cci AVHRR-PM v2.0 dataset}

The Cloud_cci AVHRR-PM v2.0 dataset (Stengel et al., 2017a) is a cloud property dataset based on 33 years of AVHRR measurements from the prime AVHRR-carrying afternoon satellites of the NOAA Polar Operational Environmental Satellites (POES) program: NOAA-07, NOAA-09, NOAA-11, NOAA-14, NOAA-16, NOAA-18 and NOAA19.

A large variety of cloud properties are included in this dataset, of which the following are used in this study: (1) cloud fraction for all clouds (CFC) and for high-, midand low-level clouds $\left(\mathrm{CFC}_{\text {high }}, \mathrm{CFC}_{\text {mid }}, \mathrm{CFC}_{\text {low }}\right),(2)$ cloudtop pressure (CTP), and (3) cloud phase ( $\mathrm{CPH}$, here represented by the liquid cloud fraction, which is the frequency of liquid clouds with respect to all clouds). The $\mathrm{CFC}, \mathrm{CFC}_{\text {high }}$, $\mathrm{CFC}_{\text {mid }}, \mathrm{CFC}_{\text {low }}$ and $\mathrm{CPH}$ data used are monthly averages, while for CTP monthly histograms were used, and all were contained in the Level-3C products defined on a $0.5^{\circ} \times 0.5^{\circ}$ latitude-longitude grid (Stengel et al., 2017b). All available Level-3C products within the time period of 1982 through 2014 were used. The underlying, initially retrieved, pixellevel cloud properties were derived using the Community Cloud retrieval for CLimate (CC4CL; Sus et al., 2018; McGarragh et al., 2018).

All remaining details of the Cloud_cci AVHRR-PM v2.0 dataset can be found in Stengel et al. (2017a), also including validation results for the cloud properties used in this study. All systematic deviations against CALIOP are repeated in Table 1 and extended by the validation scores for optical thickness thresholds $\left(\mathrm{COT}_{\mathrm{th}}\right)$ of 1.0 in addition to 0.0 and 0.15 .

Cloud_cci cloud detection is successful in $81 \%$ of all pixels, however, being characterized by an underestimation of cloud occurrence by about $13 \%$. Removing optically thin clouds from the reference data (CALIOP) clearly improves the agreement of Cloud_cci to the reference with hit rates now reaching $85 \%$ and a bias close to 0 . Removing all clouds with COT smaller than $1\left(\mathrm{COT}_{\text {th }}=1.0\right)$ from the reference deteriorates the cloud detection scores and leads to a significant positive bias (about $12 \%$ more clouds in Cloud_cci than in CALIOP). This exercise suggests that AVHRR-PM 

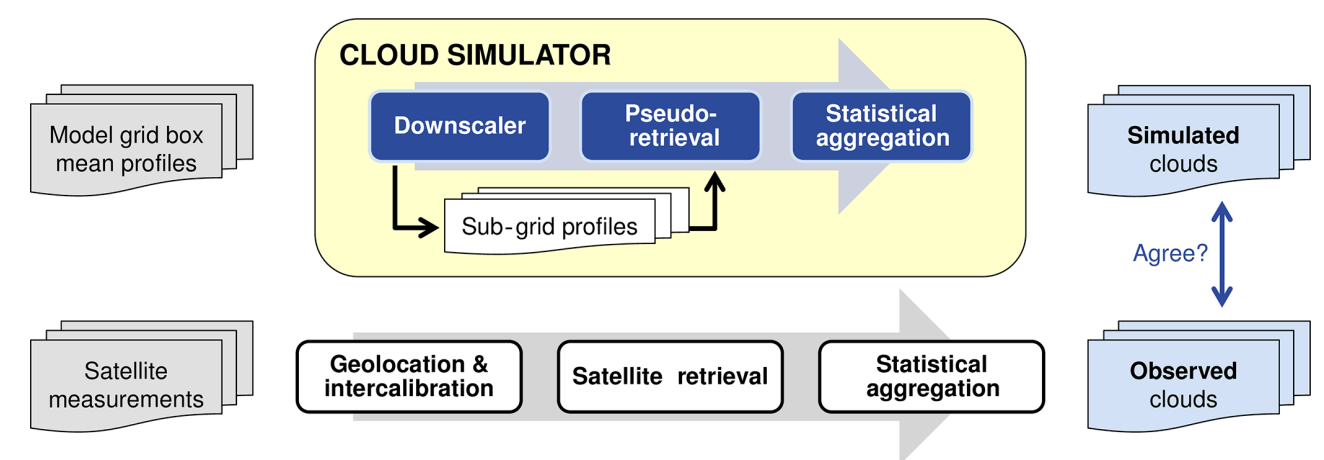

Figure 1. Schematic representation of the basic principle of the SIMFERA satellite simulator, which in many aspects is common to other satellite simulators. SIMFERA is a diagnostic tool that maps the model representation of clouds to synthetic satellite observations.

systematically misses the very thin clouds but builds a very sound reference for all clouds with COT of 0.15 and higher.

Furthermore, cloud-top height (CTH) was validated, which like CTP, is a representation of the retrieved vertical placement of the cloud top. Similar to the CFC validation COT thresholds were applied, however, here (and for $\mathrm{CPH}$ ) referring to the optical thickness into the cloud (top-down) at which the reference value was taken from the CALIOP profile.

Once the liquid phase is correctly identified, the CTH is retrieved very accurately with standard deviations below $1 \mathrm{~km}$ and biases below $130 \mathrm{~m}$. Both measures further improve when removing the very thin cloud layers at the cloud top, although this has only a minor impact on the scores for liquid clouds. For ice clouds the errors in CTH retrieval are larger than for liquid clouds in terms of standard deviations and biases. Removing the thin cloud layers at the cloud top significantly improves the quality leading to reduced standard deviations of $2.2 \mathrm{~km}$ and biases of $-0.7 \mathrm{~km}$ when selecting the reference $\mathrm{CTH}$ at $\mathrm{COT}_{\text {th }}=1.0$.

For $\mathrm{CPH}$, validation results are very similar to the cloud detection validation when compared to the reference (CALIOP). The best CPH agreement to CALIOP is found for $\mathrm{COT}_{\text {th }}=0.15$ into the cloud with a hit rate exceeding $80 \%$ here, although accompanied with a ice frequency bias of $6.9 \%$. For $\mathrm{COT}_{\text {th }}=0.0$ and $\mathrm{COT}_{\text {th }}=1.0$ hit rate scores are clearly lower.

In summary, comparisons with CALIOP have shown that Cloud_cci AVHRR-PM v2.0 data for CMA, CPH and CTH are of good quality. The detection of optically very thin cloud layers and the retrieval of their cloud phase and cloud-top pressure and height using AVHRR is difficult. This, however, could be well characterized by the presented validation results. Removing the optically very thin clouds from the statistics leads to improvements in the scores (when compared with CALIOP), approaching maximum hit rate scores for CMA and $\mathrm{CPH}$ for $\mathrm{COT}_{\text {th }}=0.15$. For $\mathrm{CTH}$, the best agreement to CALIOP is found for $\mathrm{COT}_{\text {th }}=1.0$. In addition to the global validation scores mentioned, latitudinally de- pendent systematic errors were computed and are shown as the uncertainty margin of the Cloud_cci data in the comparisons of Sect. 4.

In addition to these validation studies, the Cloud_cci data were compared to other existing climate datasets such as the Pathfinder Atmospheres - Extended dataset (PATMOS-x, Heidinger et al., 2014) and the Climate Monitoring Satellite Application Facility's (CM SAF) cloud, albedo and radiation dataset (CLARA-A2, Karlsson et al., 2016) in Stapelberg et al. (2017), which documented reasonable similarities for the cloud properties considered in this paper.

It is also important to note that an inherent feature of passive imagers is that most of the time only the uppermost cloud can be observed. This has the direct consequence that clouds covered by cloud layers above will not be detected. This limitation, however, has been accounted for in the simulator presented in Sect. 3 .

\subsection{ERA-Interim reanalysis}

The ERA-Interim global atmospheric reanalysis (Dee et al., 2011) provided by the European Centre for Medium-Range Weather Forecasts (ECMWF) is the follow-up of ERA-40 reanalysis (Uppala et al., 2005). ERA-Interim covers the period from 1979 onwards and is continuously extended operationally. One of the main objectives was to solve various difficulties regarding data assimilation (e.g. the use of satellite data), which were found during the production of ERA40. See for example (Dee et al., 2011; Mooney et al., 2011; Bao and Zhang, 2013; Betts et al., 2009) for improvements of ERA-Interim over ERA-40.

The ERA-Interim reanalysis is produced by the Integrated Forecast System (IFS) version Cy31r1, which includes the forecast model consisting of three fully coupled components for the atmosphere, land surface and ocean waves. ERAInterim clouds are represented by a fully prognostic cloud scheme in which cloud-related processes are treated in a unified way; i.e. they are physically realistic and consistent with the rest of the model. More specifically, cloud processes 
Table 1. Global validation scores of Cloud_cci AVHRR-PM v2.0 cloud mask (CMA), cloud-top height (CTH) and cloud phase (CPH) against CALIOP. For CMA the validation scores are shown as a function of a COT threshold $\left(\mathrm{COT}_{\mathrm{th}}\right)$, which is used for separating cloudy from clear-sky CALIOP pixels. For CTH and CPH the scores are also shown as a function of $\left(\mathrm{COT}_{\text {th }}\right)$, although $\left(\mathrm{COT}_{\text {th }}\right)$ is here referring to the optical thickness into the cloud (top-down) at which the reference value was taken from the CALIOP profile (SD $=\mathrm{Standard} \mathrm{deviation).}$

\begin{tabular}{|c|c|c|c|c|}
\hline & $\begin{array}{r}\text { CMA } \\
\text { Hit rate }(\%) / \text { Bias }(\%)\end{array}$ & $\begin{array}{r}\mathrm{CTH}_{\mathrm{liq}} \\
\mathrm{SD}(\mathrm{km}) / \mathrm{Bias}(\mathrm{km})\end{array}$ & $\begin{array}{r}\mathrm{CTH}_{\mathrm{ice}} \\
\mathrm{SD}(\mathrm{km}) / \mathrm{Bias}(\mathrm{km})\end{array}$ & $\begin{array}{r}\mathrm{CPH} \\
\text { Hit rate }(\%) / \mathrm{Bias}(\%)\end{array}$ \\
\hline $\mathrm{COT}_{\text {th }}=0.0$ & $81.2 /-12.6$ & $0.91 /-0.13$ & $2.84 /-2.65$ & $77.1 / 5.9$ \\
\hline $\mathrm{COT}_{\mathrm{th}}=0.15$ & $84.9 /-0.5$ & $0.97 /-0.09$ & $2.59 /-1.94$ & $80.6 /-6.9$ \\
\hline $\mathrm{COT}_{\text {th }}=1.0$ & $77.7 / 12.3$ & $0.84 / 0.05$ & $2.23 /-0.74$ & $76.0 /-18.6$ \\
\hline
\end{tabular}

are described by prognostic equations for cloud condensate and cloud fraction obeying mass balance equations (Tiedtke, 1993). Clouds are defined by the horizontal coverage of the grid box by cloud and the mass mixing ratio of total cloud condensate, along with the constraint that cloud air is saturated with regard to liquid water and ice. As time evolves in the model simulation the cloud variables change due to source and sink terms that are related to cloud formation (e.g. condensation or sublimation, cumulus convection) and destruction (e.g. evaporation, precipitation) processes, respectively. The cloud water is separated into ice and liquid portions by a temperature-dependent function between -23 and $0{ }^{\circ} \mathrm{C}$, constrained by only ice water below and only liquid water above this temperature range (ECMWF, 2007).

As for most large-scale models, the fact that only bulk properties of clouds can be taken into account is an important and indispensable limitation of ERA-Interim.

ERA-Interim in general has been used in many climate studies in the past (e.g. Screen and Simmonds, 2010; DeMott et al., 2013; Madonna et al., 2014; Simmons and Poli, 2015), including studies on clouds (e.g. Jiang et al., 2011; Cuzzone and Vavrus, 2011; Hanley and Caballero, 2012).

\section{SIMFERA - a simplified satellite simulator}

The SIMplified satellite simulator For ERA-interim (SIMFERA) reads the 6-hourly (00:00, 06:00, 12:00, 18:00 UTC) gridded, three-dimensional (3-D) model fields of meteorological upper air parameters on 60 model levels, with the top of the atmosphere located at $0.1 \mathrm{hPa}$. These model fields include liquid water content $\left(\mathrm{LWC}_{\mathrm{gbm}}\right.$ ) (the mass of condensate per mass of moist air in $\mathrm{kg} \mathrm{kg}^{-1}$ ), where the subscript gbm refers to grid box mean values, ice water content (IWC $\mathrm{gbm}$ ) in $\mathrm{kg} \mathrm{kg}^{-1}$, cloud cover, temperature $(T)$ in $\mathrm{K}$, and specific humidity $(Q)$ in $\mathrm{kg} \mathrm{kg}^{-1}$. Additionally, the data input comprise the surface geopotential $(Z)$ in $\mathrm{m}^{2} \mathrm{~s}^{-2}$ and the logarithm of surface pressure $(\mathrm{Pa})$, which are used to compute the vertical pressure and geopotential profiles at model levels.

\subsection{Preprocessing}

In the preprocessing step the $\mathrm{LWC}_{\mathrm{gbm}}$ and $\mathrm{IWC}_{\mathrm{gbm}}$ at each model level are divided by cloud cover, yielding the so-called in-cloud liquid and ice water content (LWC and IWC) at each model level. For the layers in between two consecutive levels, LWC and IWC are used to determine layer liquid and ice water path $\left(\mathrm{LWP}_{\text {lay }}\right.$ and $\left.\mathrm{IWP}_{\text {lay }}\right)$ incorporating the height of the layer.

The liquid and ice cloud optical thickness per layer $\left(\mathrm{COT}_{\text {lay }}, \mathrm{iCOT}_{\text {lay }}\right)$ are obtained by rearranging the Han et al. (1994) formulation originally defined for diagnosing LWP from COT and CER (cloud effective radius):

$\mathrm{COT}=\frac{3}{4} \frac{\mathrm{CWP} \cdot Q_{\mathrm{ext}}}{\mathrm{CER} \cdot \rho}$,

where CWP represents either LWP or IWP, depending on the thermodynamic phase. $Q_{\text {ext }}$ denotes the extinction coefficient, which is assumed to be 2 for water and 2.1 for ice. The density $\rho$ is set to $1000 \mathrm{~kg} \mathrm{~m}^{-3}$ for water and $916.7 \mathrm{~kg} \mathrm{~m}^{-3}$ for ice.

The computation of CER in SIMFERA is done as in the ERA-Interim radiation scheme. (a) Following Martin et al. (1994) for liquid clouds, $\mathrm{CER}_{\text {liq }}$ is a function of liquid water content and cloud droplet number concentration (CDNC). The needed number of cloud condensation nuclei is $300 \mathrm{~cm}^{-3}$ over land and $100 \mathrm{~cm}^{-3}$ over sea. (b) For ice clouds, $\mathrm{CER}_{\text {ice }}$ is a function of temperature and ice water content, based on Sun and Rikus (1999) and revised by Sun (2001).

\subsection{Downscaler}

The second part of the simulator addresses, firstly, the mismatch in horizontal scale between an ERA-Interim model grid box $(\sim 80 \mathrm{~km})$ and a satellite footprint $(\sim 5 \mathrm{~km}$ for AVHRR global data) and, secondly, the limitation in vertical resolution of the AVHRR-based satellite retrieval. For adjusting the spatial resolution (and for resolving sub-grid variability within a model grid cell), the vertical profiles in each model grid cell are projected onto a certain number of sub-columns, each of which can be thought of as representing an AVHRR pixel. At each model layer, the 

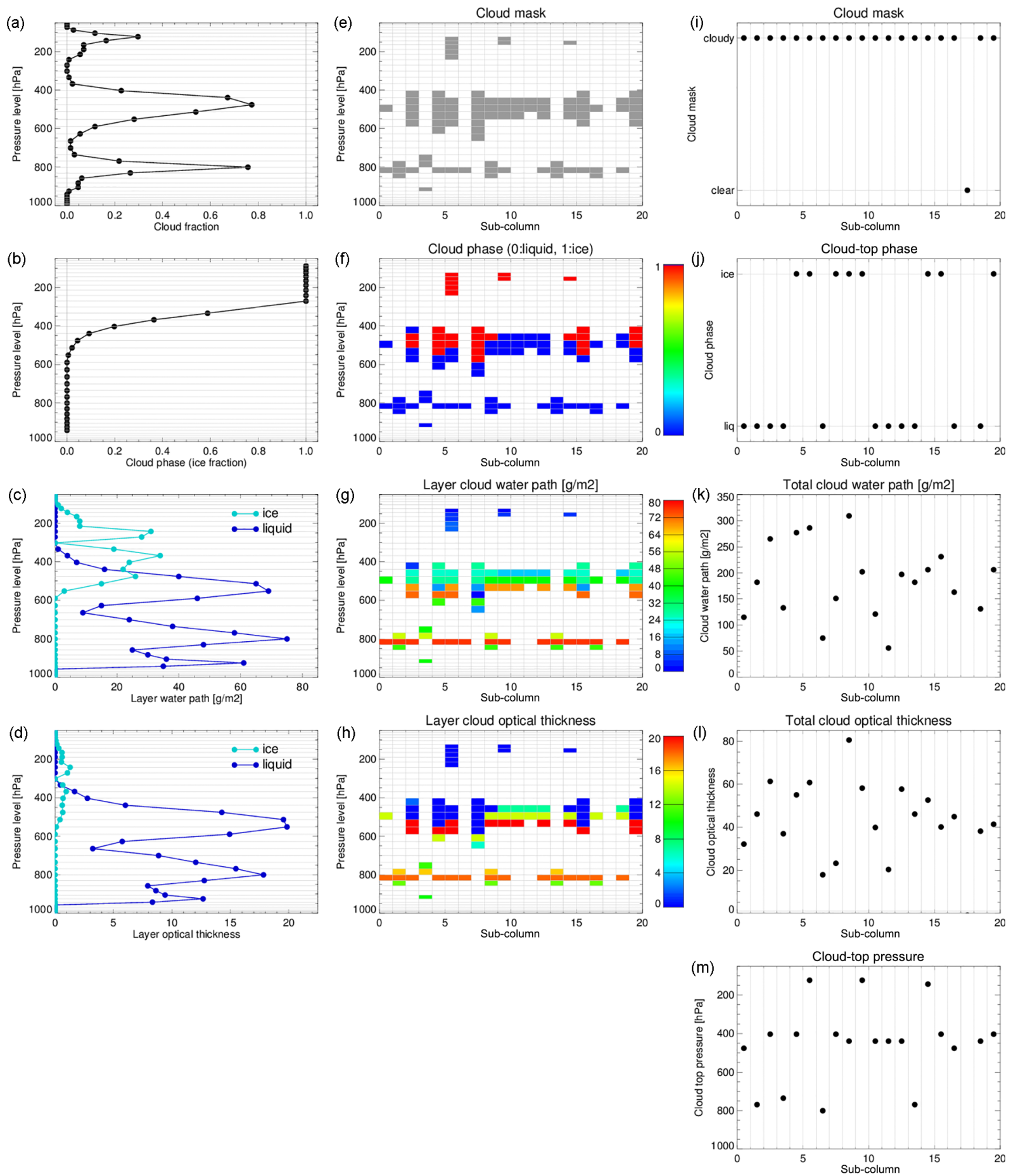

Figure 2. Example case for converting ERA-Interim grid box profiles to SIMFERA sub-columns and to pseudo-retrievals. The left column shows ERA-Interim-based profiles of cloud fraction (a), cloud phase (b), layer water path (c) and layer cloud optical thickness (d). The middle column gives the same data after columnizing into 20 sub-columns that represent the sub-grid variability and after removing the uppermost cloud layers with layer optical thicknesses below a certain threshold (here 0.15): cloud mask (e), cloud phase (f), layer water path (g, layer liquid and ice water path in liquid and ice cells) and layer optical thickness (h, layer liquid and ice optical thickness in liquid and ice cells). The right panels show vertically summarized values per sub-column (also called pseudo-retrieval): cloud mask (i), cloud-top phase (j), vertically integrated water path (k), vertically integrated optical thickness (l) and cloud-top pressure (m). Each of these sub-column representative values can be seen as an individual pseudo satellite retrieval. 


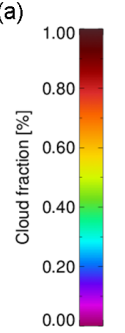

(c)

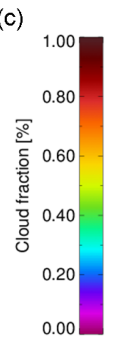

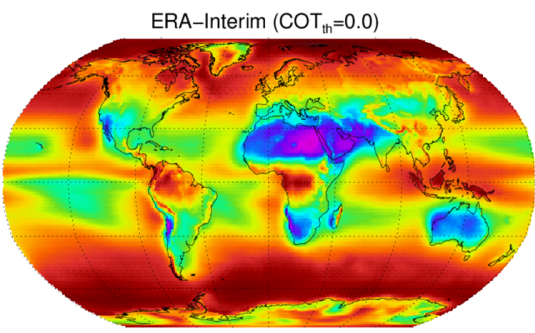

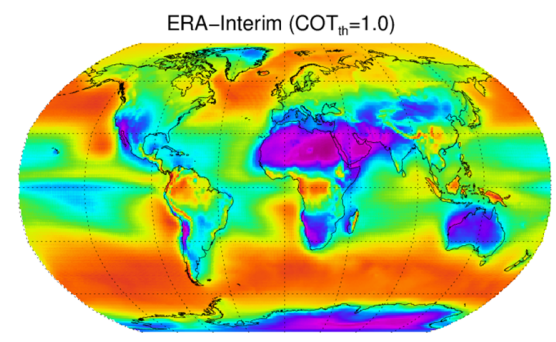

(e)

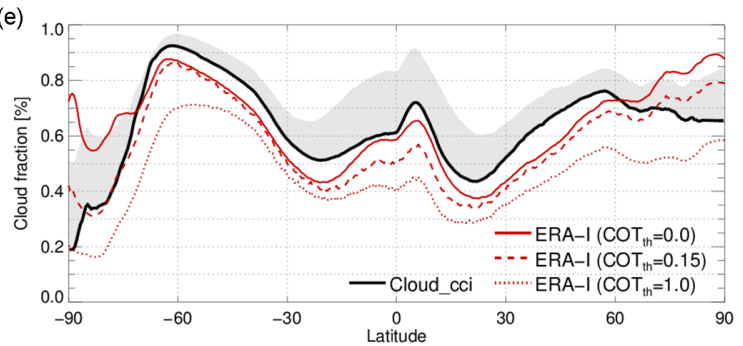

(b)
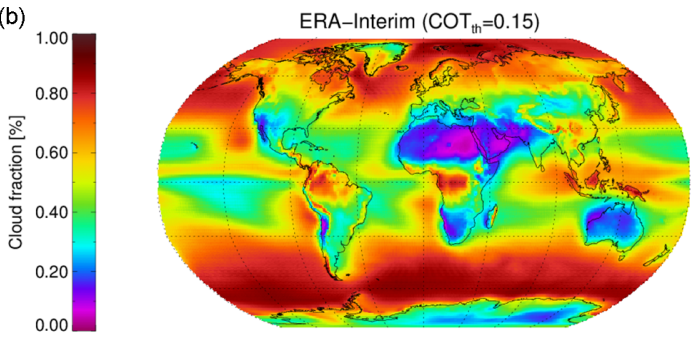

(d)
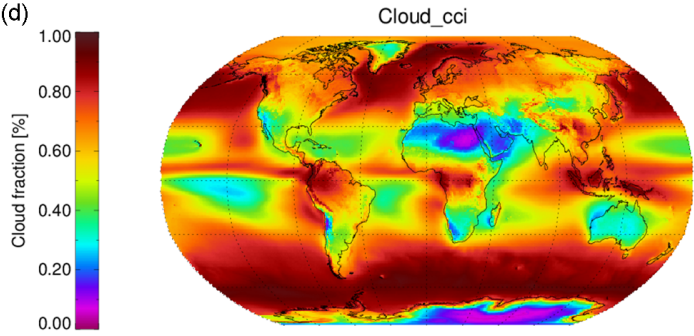

Figure 3. Multi-annual mean cloud fraction (CFC) from ERA-Interim (a-c) and Cloud_cci (d), where the ERA-Interim cloud fraction was produced by SIMFERA for three optical thickness thresholds $\left(\mathrm{COT}_{\mathrm{th}}=0.0,0.15,1.0\right)$. Panel (e) is the zonal mean plot of CFC for all four sets. The grey shaded area corresponds to the estimated systematic uncertainty in Cloud_cci CFC based on comparisons to CALIOP. The uncertainty in Cloud_cci is mainly due to missing optically very thin clouds.

downscaler distributes the grid cell cloud fraction randomly onto the sub-columns. Clouds occurring in layers on top of each other (vertically neighbouring layers) are assumed to overlap maximally, while vertically separated cloud layers are assumed to have a random overlap. This procedure follows the maximum-random overlap approach of Geleyn and Hollingsworth (1979). This approach for deriving sub-grid profiles is very similar to SCOPS (Subgrid Cloud Overlap Profile Sampler, Webb et al., 2001), which is implemented, for instance, in COSP.

Figure 2 visualizes the results of the preprocessing and downscaling for a randomly selected case. To summarize, the preprocessing calculates $\mathrm{LWC}$ and IWC from $\mathrm{LWC}_{\mathrm{gbm}}$ and $\mathrm{IWC}_{\mathrm{gbm}}$, which are further processed to $\mathrm{LWP}_{\text {lay }}$ and $\mathrm{IWP}_{\text {lay }}$ (for each of the $M$ model layers; panel c), which are in turn used to calculate $\mathrm{ICOT}_{\text {lay }}$ and $\mathrm{iCOT}_{\text {lay }}$, the liquid and ice optical thickness per layer (panel d). The downscaler creates a $N$-by- $M$ matrix for each model grid cell with $N$ being the number of sub-columns. In the framework of this study, $N=20$ was used, which on the one hand resembles a sub-grid at a coarser resolution compared to the resolution of the AVHRR GAC data. On the other hand, this number was found to be a good compromise as no significant change in the later calculated grid-mean values was detectable compared to larger $N$ values, while the computational expense increases linearly with increasing $N$. All cells in the $N$-by$M$ matrix can be either cloudy (1) or not cloudy (0), and the cloudy cells can be of liquid or ice phase. Depending on the phase of each cell, the COT matrix is filled with $\mathrm{ICOT}_{\text {lay }}$ or $\mathrm{iCOT}_{\text {lay }}$ and the CWP matrix with $\mathrm{LWP}_{\text {lay }}$ or $\mathrm{IWP}_{\text {lay }}$. In each sub-column, all uppermost cloud cells for which the top-down, vertically integrated COT is smaller than the chosen COT threshold are removed. In case the total COT in a sub-column is smaller then the threshold, that sub-column is counted as clear. In this study three different COT thresholds were used: $\mathrm{COT}_{\text {th }}=0.0, \mathrm{COT}_{\text {th }}=0.15$ and $\mathrm{COT}_{\text {th }}=1.0$. Choosing these thresholds was motivated by generally assessing the sensitivity of the ERA-Interim clouds and the comparison results to the value of the threshold. Furthermore, the chosen thresholds correspond directly to the values used in the validation of Cloud_cci data against CALIOP (in which the threshold is applied to CALIOP profiles; see Sect. 2.1), which provide error margins used as observation uncertainties in this study. 
Table 2. SIMFERA output of monthly mean cloud properties. Bold font marks properties used for comparisons to observations in this study. The separation of low, mid-level and high clouds at 680 and $440 \mathrm{hPa}$ for $\mathrm{CFC}_{\text {low }}, \mathrm{CFC}_{\text {mid }}$ and $\mathrm{CFC}_{\text {high }}$ follows (Rossow and Schiffer, 1999).

\begin{tabular}{|c|c|c|c|}
\hline Variable name & Abbrev. & Unit & Description \\
\hline Total cloud fraction & $\mathrm{CFC}$ & 1 & Total cloud fraction (all clouds) \\
\hline Low-level cloud fraction & $\mathrm{CFC}_{\text {low }}$ & 1 & Fraction of low-level clouds with CTP larger than $680 \mathrm{hPa}$ \\
\hline Mid-level cloud fraction & $\mathrm{CFC}_{\text {mid }}$ & 1 & Fraction of mid-level clouds with CTP between 680 and $440 \mathrm{hPa}$ \\
\hline High-level cloud fraction & $\mathrm{CFC}_{\text {high }}$ & 1 & Fraction of high-level clouds with CTP lower than $440 \mathrm{hPa}$ \\
\hline Liquid cloud fraction & $\mathrm{CPH}$ & 1 & Fraction of liquid clouds with respect to all clouds \\
\hline Cloud-top pressure & CTP & $\mathrm{hPa}$ & Pressure level at uppermost cloud layer top \\
\hline Cloud-top height & $\mathrm{CTH}$ & $\mathrm{km}$ & Derived from CTP and atmospheric profile \\
\hline Cloud-top temperature & CTT & $\mathrm{K}$ & Derived from CTP and atmospheric profile \\
\hline Cloud effective radius & CER & $\mu \mathrm{m}$ & $\begin{array}{l}\text { Effective particle radius at cloud top (additionally stratified by cloud-top phase } \\
\left.\left(\mathrm{CER}_{\text {liq }}, \mathrm{CER}_{\text {ice }}\right)\right)\end{array}$ \\
\hline Cloud optical thickness & COT & 1 & $\begin{array}{l}\text { Vertical integrated cloud optical thickness (additionally stratified by cloud-top } \\
\text { phase }\left(\mathrm{COT}_{\text {liq }}, \mathrm{COT}_{\text {ice }}\right) \text { ) }\end{array}$ \\
\hline Cloud liquid water path & LWP & $\mathrm{g} \mathrm{m}^{-2}$ & Vertical integrated cloud water path of liquid clouds \\
\hline Cloud ice water path & IWP & $\mathrm{g} \mathrm{m}^{-2}$ & Vertical integrated cloud water path of ice clouds \\
\hline
\end{tabular}

It should be noted that applying a threshold of $\mathrm{COT}_{\text {th }}=$ 0.0 is a good approximation of not using a simulator at all when considering CFC because no clouds are excluded from the statistics. For cloud-top properties, such as $\mathrm{CPH}$ and $\mathrm{CTH}$, the application of a simulator is mandatory since these properties are not included in the standard reanalysis output. Indeed, the application of a simulator, in particular the application of a COT threshold, can significantly alter the model cloud fields occasionally. In an extreme case a very high, optically thin ice cloud which overlaps with a very low liquid cloud might be removed from the model cloud fields when the simulator is applied, resulting in only the high CTP and a liquid cloud being reported in the simulator output. This, however, is just correctly reflecting the limitations of the passive imager capabilities. The impact of this approach is reflected by applying different COT thresholds (including $\mathrm{COT}_{\text {th }}=0.0$, which means no cloud layers are removed) as mentioned above.

\subsection{Pseudo-retrieval and data aggregation}

As the spatial scales of the sub-column (Fig. 2e-h) now represent those of AVHRR pixels, a pseudo-retrieval is done for each sub-column based on its vertical cloud distribution. CTP, CER and CPH are collected from the uppermost cloud layer. COT and CWP are integrated over the entire column. If a sub-column does not contain a single cloud cell it is assigned to be clear, otherwise cloudy.

Figure 2 further shows the pseudo-retrievals for each subcolumn (panels $\mathrm{i}-\mathrm{m}$ ) for the presented example case. CTP values are additionally converted to cloud-top height and cloud-top temperature (CTT). COT, CER and CWP are not considered during twilight and night-time conditions (sun zenith angles above $75^{\circ}$ ) to be consistent with the observational data.
All pseudo-retrievals from all sub-columns are used as input for aggregating monthly properties (averages and histograms) on a latitude-longitude grid of $0.5^{\circ}$ resolution. A list of monthly mean cloud properties produced by SIMFERA is shown in Table 2. Spatially resolved histograms are composed following the Cloud_cci definition (see Table 5 of Stengel et al., 2017a) with all histograms being compiled for liquid and ice clouds separately. As CTP histograms are used later in this study, their bin borders are repeated here: $\{1,90$, $180,245,310,375,440,500,560,620,680,740,800,875$, $950,1100\} \mathrm{hPa}$.

For the comparisons shown and discussed in Sect. 4, SIMFERA was applied to ERA-Interim data from 1982 to 2014.

\section{Comparison of ERA-Interim and Cloud_cci cloud properties}

In this section the cloud properties of ERA-Interim, which have been adjusted by SIMFERA to simulate satellite retrieved properties, are compared against the observed properties of the Cloud_cci AVHRR-PM v2.0 dataset by considering monthly $\mathrm{CFC}, \mathrm{CFC}_{\text {low }}, \mathrm{CFC}_{\text {mid }}, \mathrm{CFC}_{\text {high }}$ and $\mathrm{CPH}$ mean fields as well as monthly CTP histograms. In addition, monthly mean and histogram fields of both data sources were averaged and aggregated to multi-annual properties within the time period of 1982 to 2014 (33 years). ERA-Interim cloud properties are presented 3 -fold by applying three different COT thresholds as described in Sect. 3.2. For all zonal mean comparisons, the estimated systematic uncertainty of Cloud_cci data is given to facilitate a better interpretation of the results. 

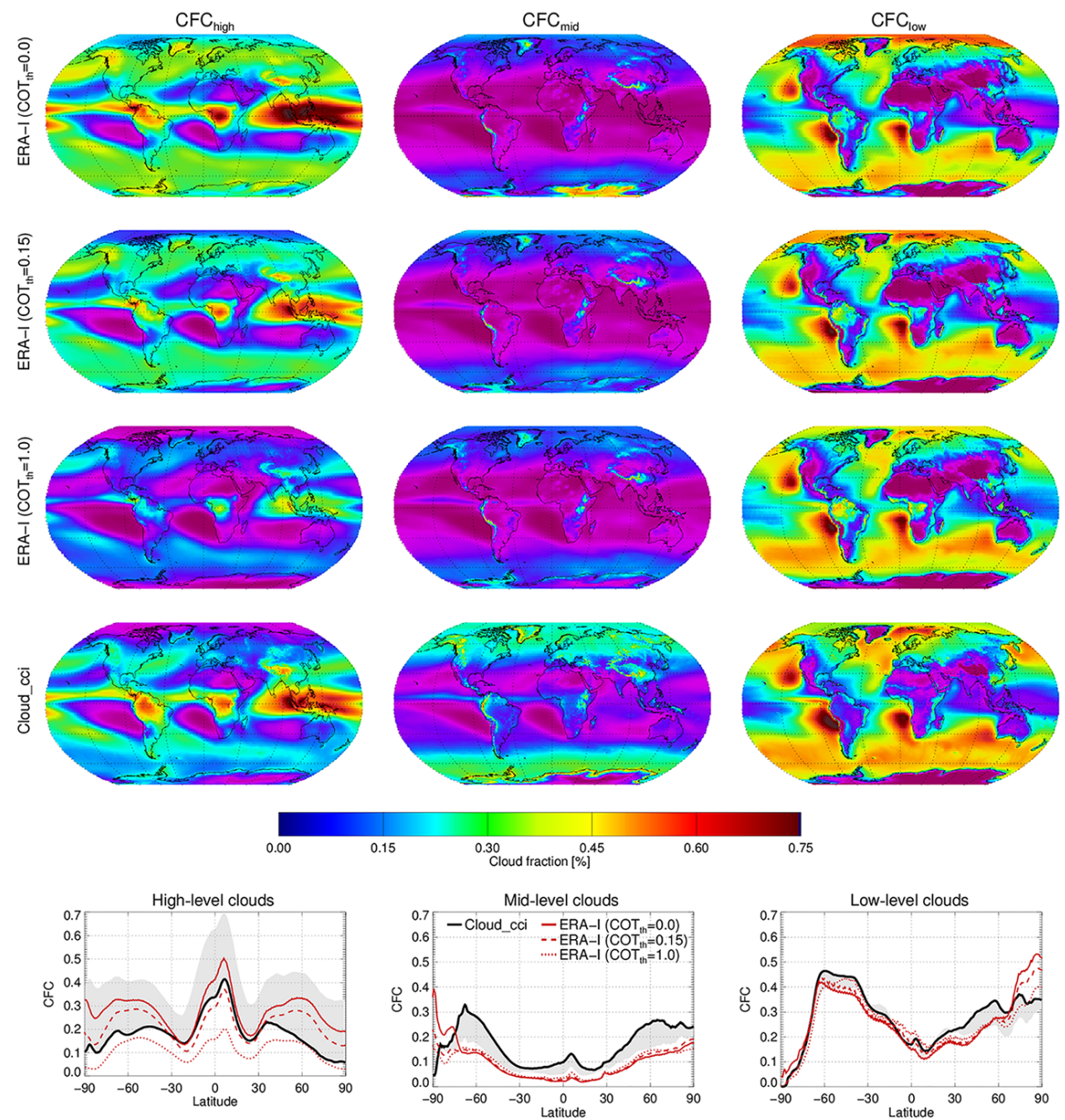

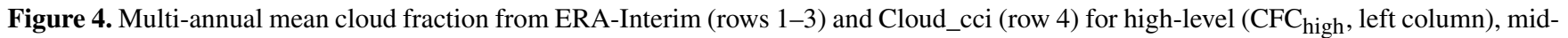
level $\left(\mathrm{CFC}_{\text {mid }}\right.$, middle column) and low-level clouds $\left(\mathrm{CFC}_{\text {low }}\right.$, right column). The ERA-Interim cloud fraction was produced by SIMFERA for three optical thickness thresholds $\left(\mathrm{COT}_{\text {th }}=0.0,0.15,1.0\right.$; rows 1 to 3 , respectively). Bottom row: zonal mean plots with grey shaded areas showing the estimated uncertainty in Cloud_cci $\mathrm{CFC}_{\mathrm{high}}, \mathrm{CFC}_{\text {mid }}$ and $\mathrm{CFC}_{\text {low }}$ based on comparisons to CALIOP.
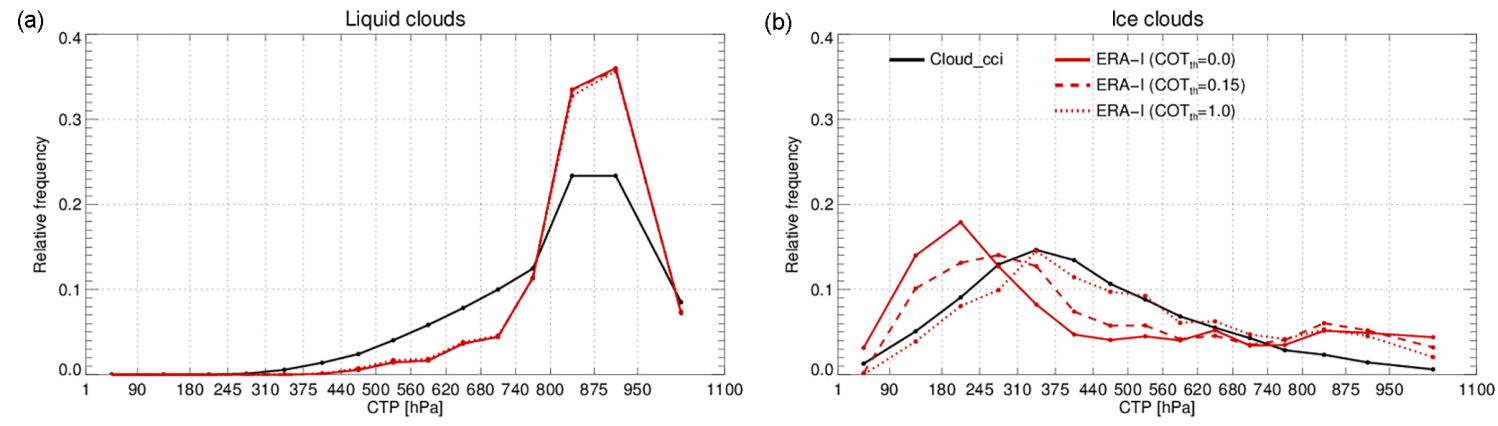

Figure 5. Global, multi-annual relative frequency histograms of observed Cloud_cci cloud-top pressure (CTP) compared to ERA-Interim CTP after applying SIMFERA with three COT thresholds (0.0, 0.15 and 1.00) - separated in liquid (a) and ice clouds (b). 


\subsection{Cloud fraction}

Figure 3 shows multi-annual mean CFC for Cloud_cci AVHRR-PM data and for ERA-Interim. In general, ERAInterim clouds present very similar global patterns compared to Cloud_cci, with high cloud fractions in the mid- and high-latitude storm track regions, in the Arctic, in the inner tropics and in regions with persistent marine stratocumulus. Low cloud fractions are in particular found in the subtropical subsidence regions. When considering all clouds in ERA-Interim $\left(\mathrm{COT}_{\text {th }}=0.0\right)$ a general underestimation of CFC is, however, found compared to Cloud_cci. This underestimation in ERA-Interim is outside the estimated systematic uncertainty of Cloud_cci. Exceptions are the polar regions in which ERA-Interim has significantly higher CFC than Cloud_cci, even outside the reported uncertainty range. The general underestimation of CFC in ERA-Interim outside the polar regions is in line with results found by Free et al. (2016) for the continental US. Removing the optically thin clouds from ERA-Interim, which had been found to be under-represented in Cloud_cci, further increases the underestimation of ERA-Interim CFC compared to Cloud_cci between $60^{\circ} \mathrm{S}$ and $60^{\circ} \mathrm{N}$. The reduction in CFC, when removing the optically thin clouds, is highest in the polar regions; e.g. over Antarctica more than $20 \%$ of all clouds in ERAInterim have optical thicknesses lower than 0.15. Removing all clouds with an optical thickness below 1 leads to a further reduction in CFC, most prominently in the high latitudes and polar regions. The agreement between the two datasets and the sensitivity of ERA-Interim to changes in $\mathrm{COT}_{\text {th }}$ are remarkably different for different cloud levels, which is elaborated on in the next subsection.

\subsection{Vertical cloud distribution}

Figure 4 shows multi-annual mean cloud fraction for three vertical layers: $\mathrm{CFC}_{\text {high }}, \mathrm{CFC}_{\text {mid }}$ and $\mathrm{CFC}_{\text {low }}$. In contrast to the total cloud fraction, for which a significant underestimation was found in ERA-Interim, the high cloud fraction reveals partly opposite characteristics. Many more high clouds are found in ERA-Interim than in Cloud_cci. The difference amounts up to $20 \%$ cloud fraction, being largest in the mid and higher latitudes, but also in the tropics, where the difference is approximately $10 \%$. In the Cloud_cci dataset, $\mathrm{CFC}_{\text {high }}$ also has the highest systematic uncertainty as again shown by the grey shading embedding the ERA-Interim results. Removing the optically thin clouds from ERA-Interim reduces the $\mathrm{CFC}_{\text {high }}$ significantly, highlighting the large contribution of optically thin clouds to ERA-Interim $\mathrm{CFC}_{\text {high }}$. When applying $\mathrm{COT}_{\text {th }}=0.15$, ERA-Interim $\mathrm{CFC}_{\text {high }}$ drops by $5 \%$ to $10 \%$ - still being higher than Cloud_cci in the mid and high latitudes. In the tropics, ERA-Interim $\mathrm{CFC}_{\text {high }}$ is already lower than Cloud_cci in this set-up. For $\mathrm{COT}_{\text {th }}=1.0$ ERA-Interim $\mathrm{CFC}_{\text {high }}$ is more than halved and lower than Cloud_cci for all latitudes.
Considering mid-level clouds, the ERA-Interim cloud fraction is lower than in Cloud_cci. The difference in $\mathrm{CFC}_{\text {mid }}$ is about $5 \%$ to $10 \%$, correlating with the amount of $\mathrm{CFC}_{\text {mid }}$. The systematic uncertainty in Cloud_cci $\mathrm{CFC}_{\text {mid }}$ has a different sign compared to $\mathrm{CFC}_{\text {high }}$, which is assumed to be a result of high clouds being classified as mid-level clouds, as the CTP retrieval in Cloud_cci is biased high for these thin clouds. The ERA-Interim $\mathrm{CFC}_{\text {mid }}$ has nearly no sensitivity to the varying $\mathrm{COT}_{\text {th }}$ (except over Antarctica), showing a very small increase in $\mathrm{CFC}_{\text {mid }}$ for increasing $\mathrm{COT}_{\text {th }}$. This is probably due to fewer clouds leaving the mid-level cloud class than being added from the high-level cloud class for increasing $\mathrm{COT}_{\text {th }}$. Generally, ERA-Interim $\mathrm{CFC}_{\text {mid }}$ lies slightly outside the Cloud_cci uncertainty range, indicating too few midlevel clouds in ERA-Interim.

For low clouds a good agreement of ERA-Interim $\mathrm{CFC}_{\text {low }}$ with Cloud_cci is found, the difference being within $10 \%$. ERA-Interim has fewer clouds than Cloud_cci for nearly all latitudes except in the Arctic regions, where ERA-Interim is about $10 \%$ higher than Cloud_cci, and some parts of the tropics, where $\mathrm{CFC}_{\text {low }}$ is nearly equal between both datasets. Looking at the global maps of $\mathrm{CFC}_{\text {low }}$, the agreement of the spatial patterns between ERA-Interim and Cloud_cci is remarkable. Similar to mid-level clouds, very little change is found for ERA-Interim $\mathrm{CFC}_{\text {low }}$ when varying $\mathrm{COT}_{\text {th }}$, which can have a similar reason as discussed above for mid-level clouds. In addition, low-level clouds are mainly water clouds, which usually have COTs higher than 1.0 anyway.

Figure 5 reports one-dimensional CTP histograms from ERA-Interim and Cloud_cci, separately for liquid and ice clouds. For liquid clouds there is a negligible impact of the applied COT thresholds on the CTP, as the histograms do not change significantly. This can be explained by the generally high COT of liquid clouds. The agreement between Cloud_cci and ERA-Interim histograms is generally good for liquid clouds, with the histograms of both datasets peaking around $875 \mathrm{hPa}$. It is assumed that the histograms would fit even better if the ERA-Interim clouds would be allowed to remain supercooled to lower temperatures, which would add some mid-level liquid clouds to the histograms and, at the same time, lower the relative frequency of low-level clouds.

When considering ice clouds, applying different COT thresholds for inferring CTP has a significant impact as visible in panel (b) of Fig. 5. When applying no threshold $\left(\mathrm{COT}_{\text {th }}=0.0\right)$, the ERA-Interim histogram for ice clouds peaks very high around $200 \mathrm{hPa}$. This maximum becomes broader and moves to lower levels (higher CTPs) when $\mathrm{COT}_{\text {th }}=0.15$ and $\mathrm{COT}_{\text {th }}=1.0$ are applied. For $\mathrm{COT}_{\text {th }}=1.0$ the ERA-Interim histogram fits the Cloud_cci data quite well. An exception occurs at lower levels, where, nearly insensitive to the applied threshold, higher ice cloud frequencies are found in ERA-Interim. Further analysis revealed that these low-level ice clouds are located in high-latitude regions (not shown). It can be speculated that these low ice clouds exist at relatively warm sub-zero temperatures and would disap- 
(a)
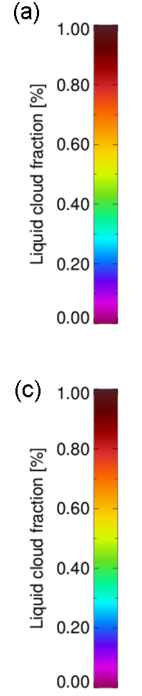

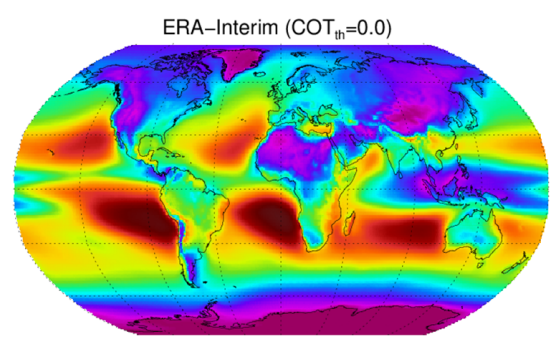

ERA-Interim $\left(\mathrm{COT}_{\text {th }}=1.0\right)$

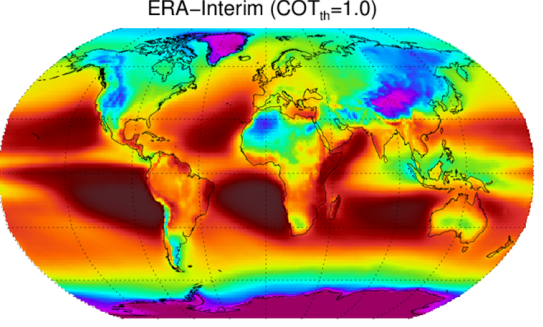

(b)
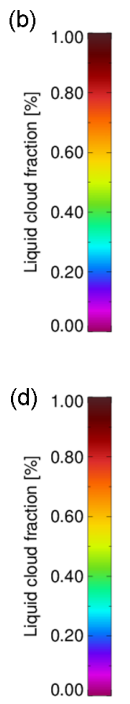

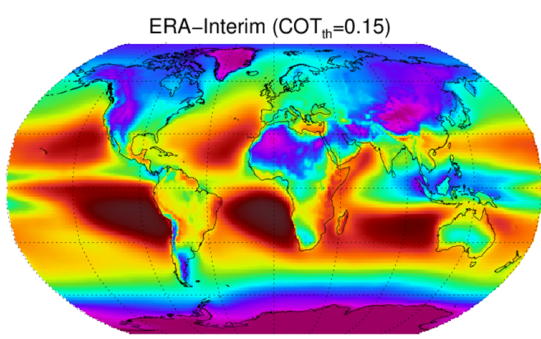

Cloud_cci

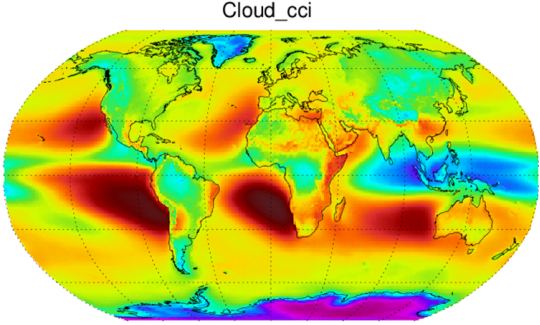

(e) $1.0 \quad-$ Cloud_cci - ERA-I $\left(\right.$ COT $\left._{\text {th }}=0.0\right)$

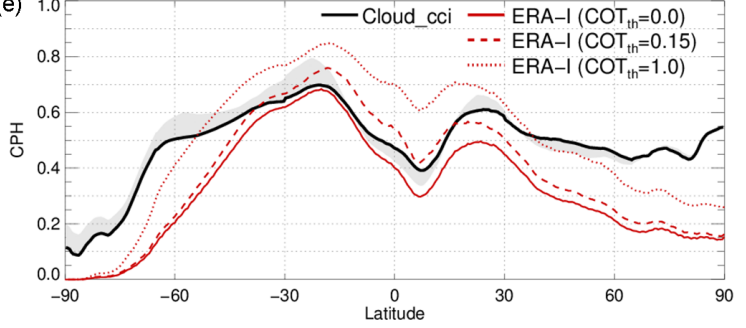

Figure 6. Multi-annual mean cloud phase $(\mathrm{CPH})$, presented as liquid cloud fraction, from ERA-Interim (a-c) and Cloud_cci (d), where the ERA-Interim liquid cloud fraction was produced by SIMFERA for three top-down optical thickness thresholds $($ COT th $=0.0,0.15,1.0)$, at which the phase was collected from ERA-Interim profiles. (e) Zonal mean plot of CPH for all four sets. The grey shaded area corresponds to the estimated uncertainty in Cloud_cci CPH based on comparisons to CALIOP.

pear from the ice statistics if liquid cloud water were allowed to remain liquid into lower temperatures in ERA-Interim.

\subsection{Cloud thermodynamic phase}

Figure 6 shows multi-annual mean $\mathrm{CPH}$ for Cloud_cci AVHRR-PM data and for ERA-Interim, the latter processed through SIMFERA for $\mathrm{COT}_{\text {th }}$ of $0.0,0.15$ and 1.0. A general similarity of the global patterns of ERA-Interim to Cloud_cci is found with, for example, very high $\mathrm{CPH}$ in the marine stratocumulus regions, relatively lower values in the inner tropics and lowest CPH values over Antarctica. However, the differences between ERA-Interim and Cloud_cci are large in the mid and high latitudes, where $\mathrm{CPH}$ drops much more in ERA-Interim than in Cloud_cci, meaning that ERA-Interim has much higher relative ice cloud frequencies. The occurrence of too few liquid clouds for sub-zero temperature in ERA-Interim is likely caused by a too-strict, linear, liquid-toice conversion suppressing all liquid clouds below $-23^{\circ} \mathrm{C}$. This would be in line with the discussion about the CTP histograms in the previous paragraph. This issue was also addressed in Forbes et al. (2016), according to which too few liquid clouds caused too-low, top-of-atmosphere upward so- lar radiation, although their study was limited to cold air outbreaks north of the Antarctic ice shield.

When applying $\mathrm{COT}_{\text {th }}=0.15$ or $\mathrm{COT}_{\text {th }}=1.0$ more liquid clouds are sampled (increase in CPH) in ERA-Interim, relatively speaking, which seems natural as lower levels usually have higher temperatures than the levels above. While the increase in ERA-Interim CPH is only moderate for $\mathrm{COT}_{\text {th }}=$ 0.15 compared to $\mathrm{COT}_{\text {th }}=0$ (increase of about $10 \% \mathrm{CPH}$ in the tropics and decreasing impact with higher latitudes), the $\mathrm{CPH}$ increase is large for $\mathrm{COT}_{\text {th }}=1.0$ (up to $30 \%$ nearly everywhere). The uncertainty in Cloud_cci (an estimate of which is shown as the grey shaded area in Fig. 6e) is rather small and cannot explain the found differences between ERA-Interim and Cloud_cci.

\section{Summary and conclusions}

Global atmospheric models are usually not capable of resolving small-scale, sub-grid processes related to clouds and therefore use prognostic cloud schemes including parametrizations for connecting grid box variables to subgrid processes. This is not only true for GCMs, but also for 
atmospheric reanalyses, which employ numerical weather prediction models over multiple decades of data. On the one hand, reanalysis datasets can be considered to be very accurate, e.g. for thermodynamic profiles such as temperature and moisture, due to the cyclic data assimilation conducted. On the other hand, their cloud properties are still modelled exclusively, giving the opportunity to evaluate the cloud-related parametrizations used (which are closely related to those of GCMs) with observations. Satellite observations are the only source that can provide reference observations with global coverage and at spatial scales of clouds. However, to overcome the mismatch in spatial scales and in representativeness between models and satellite observations, satellite simulators are necessary.

In this study a simplified satellite simulator (called SIMFERA) is introduced and applied to ERA-Interim fields with a focus on cloud properties. Like already existing satellite simulators, SIMFERA is used to convert the model state into pseudo satellite observations. The inputs to SIMFERA are basic model output fields (e.g. temperature, moisture, cloud cover and cloud condensate), complemented by using model parametrizations for those properties not directly available, such as effective radius. More complex simulators often use synthetic radiances determined by a radiative transfer model (RTM) using the model fields as input to derive synthetic retrievals of cloud properties. Most commonly they are run online (as part of COSP, for example) using temporarily available model fields such as optical properties. Unlike these, SIMFERA can be run offline on high temporal resolution basic model output, keeping modifications to a minimum and mainly tackling the difference in horizontal and vertical scales and resolutions. This approach enables more flexibility of the simulator and supports a clearer backpropagation of the results of comparisons to observations to actual model deficiencies. In more detail, SIMFERA is built up of three modules: (1) a preprocessor, which determines all necessary input data from available model fields for each grid box; (2) a downscaler, which converts the model grid box mean profiles to sub-grid column profiles considering the sub-grid variability and the finer spatial resolution of the satellite pixel; and (3) pseudo-retrieval, which emulates the pixel-scale cloud property retrieval per column followed by statistical aggregation, which is strongly aligned with the content of the observational dataset (e.g. temporal averages and histograms). In summary, un-averaged model fields, such as available from ERA-Interim reanalysis, undergo the SIMFERA adjustment and are then aggregated to mimic existing satellite-based cloud climatologies such as the Cloud_cci AVHRR-PM dataset. This dataset was then used in subsequent comparisons (for the period of 1982-2014) acting as a reference and including estimates of systematic uncertainties.

The comparisons reveal that in terms of global patterns, ERA-Interim total cloud fraction agrees very well with the observations. However, it is biased low nearly everywhere on the globe. This underestimation amounts to approximately $10 \%$. Exceptions are the polar regions, in which ERAInterim has partly much higher cloud fraction than the observations. This is caused by the occurrence of very thin clouds, as the overestimation disappears when clouds with low optical thicknesses are filtered out. The analysis further revealed that the underestimation in total cloud fraction is mainly caused by a lack of mid-level and low clouds, although the spatial patterns agree well in particular for low clouds. High cloud occurrence in ERA-Interim agrees to the observations within their uncertainties. With respect to cloud phase, it is found that ERA-Interim has a significant ice bias. This bias in the corresponding liquid cloud fraction amounts partly to $30 \%$ and is most pronounced in the northern mid-latitudes, and northern and southern hemispheric polar regions. It is very likely that this is caused by the suppression of liquid clouds below $-23^{\circ} \mathrm{C}$ in ERA-Interim cloud schemes.

In upcoming versions of the Cloud_cci datasets, optical and microphysical cloud properties will be improved, facilitating the evaluation of corresponding modelled equivalents of those as well.

Code availability. The SIMFERA code is available through the following repository: https://github.com/martinstengel/simfera (Stengel and Schlundt, 2018).

Author contributions. MS and CS conducted the study and composed the manuscript. CS and MS designed, implemented and ran the simplified simulator. SE helped in developing the simulator concept, e.g. with respect to sub-grid cloud properties. OS and SS provided the observational data and helped in aligning the simplified simulator output to represent the observed cloud properties. UW and JFM provided expertise on modelled clouds in reanalyses and the evaluation of them using observations. All authors contributed to interpreting the results and to the finalization and revision of the manuscript.

Competing interests. The authors declare that they have no conflict of interest.

Acknowledgements. This work was supported by the European Space Agency through the Cloud_cci project (contract no. $4000109870 / 13 / \mathrm{I}-\mathrm{NB})$.

Edited by: Hailong Wang

Reviewed by: two anonymous referees

\section{References}

Bao, X. and Zhang, F.: Evaluation of NCEP-CFSR, NCEP-NCAR, ERA-Interim, and ERA-40 Reanalysis Datasets against Indepen- 
dent Sounding Observations over the Tibetan Plateau, J. Clim., 26, 206-214, https://doi.org/10.1175/JCLI-D-12-00056.1, 2013.

Betts, A. K., Köhler, M., and Zhang, Y.: Comparison of river basin hydrometeorology in ERA-Interim and ERA-40 reanalyses with observations, J. Geophys. Res.-Atmos., 114, D02101, https://doi.org/10.1029/2008JD010761, 2009.

Bodas-Salcedo, A., Webb, M. J., Bony, S., Chepfer, H., Dufresne, J.-L., Klein, S. A., Zhang, Y., Marchand, R., Haynes, J. M., Pincus, R., and John, V. O.: COSP: Satellite simulation software for model assessment, Bull. Am. Meteorol. Soc., 92, 1023-1043, https://doi.org/10.1175/2011BAMS2856.1, 2011.

Boucher, O., Randall, D., Artaxo, P., Bretherton, C., Feingold, G., Forster, P., Kerminen, V.-M., Kondo, Y., Liao, H., Lohmann, U., Rasch, P., Satheesh, S., Sherwood, S., Stevens, B., and Zhang, X.: Clouds and Aerosols, Cambridge University Press, Cambridge, United Kingdom and New York, NY, USA, book section 7, 571658, https://doi.org/10.1017/CBO9781107415324.016, 2013.

Cesana, G., Kay, J., Chepfer, H., English, J., and Boer, G.: Ubiquitous low-level liquid-containing Arctic clouds: New observations and climate model constraints from CALIPSO-GOCCP, Geophys. Res. Lett., 39, https://doi.org/10.1029/2012GL053385, 2012.

Cuzzone, J. and Vavrus, S.: The relationships between Arctic sea ice and cloud-related variables in the ERA-Interim reanalysis and CCSM3, Environ. Res. Lett., 6, 014016, https://doi.org/10.1088/1748-9326/6/1/014016, 2011.

Dai, A., Karl, T. R., Sun, B., and Trenberth, K. E.: Recent trends in cloudiness over the United States: A tale of monitoring inadequacies, Bull. Am. Meteorol. Soc., 87, 597-606, 2006.

Dee, D. P., Uppala, S. M., Simmons, A. J., Berrisford, P., Poli, P., Kobayashi, S., Andrae, U., Balmaseda, M. A., Balsamo, G., Bauer, P., Bechtold, P., Beljaars, A. C. M., van de Berg, L., Bidlot, J., Bormann, N., Delsol, C., Dragani, R., Fuentes, M., Geer, A. J., Haimberger, L., Healy, S. B., Hersbach, H., Hólm, E. V., Isaksen, L., Kållberg, P., Köhler, M., Matricardi, M., McNally, A. P., Monge-Sanz, B. M., Morcrette, J.-J., Park, B.-K., Peubey, C., de Rosnay, P., Tavolato, C., Thépaut, J.-N., and Vitart, F.: The ERA-Interim reanalysis: configuration and performance of the data assimilation system, Q. J. Roy. Meteor. Soc., 137, 553-597, https://doi.org/10.1002/qj.828, 2011.

DeMott, C. A., Stan, C., and Randall, D. A.: Northward propagation mechanisms of the boreal summer intraseasonal oscillation in the ERA-Interim and SP-CCSM, J. Clim., 26, 1973-1992, 2013.

Dufresne, J.-L. and Bony, S.: An Assessment of the Primary Sources of Spread of Global Warming Estimates from Coupled Atmosphere-Ocean Models, J. Clim., 21, 5135-5144, https://doi.org/10.1175/2008JCLI2239.1, 2008.

ECMWF: Part IV: Physical Processes, IFS Documentation, ECMWF, https://www.ecmwf.int/sites/default/files/elibrary/ 2007/9221-part-iv-physical-processes.pdf (last access: 5 December 2018), operational implementation 12 September 2006, 2007.

Eliasson, S., Buehler, S. A., Milz, M., Eriksson, P., and John, V. O.: Assessing observed and modelled spatial distributions of ice water path using satellite data, Atmos. Chem. Phys., 11, 375391, https://doi.org/10.5194/acp-11-375-2011, 2011.

Forbes, R., Geer, A., Lonitz, K., and Ahlgrimm, M.: Reducing systematic errors in cold-air outbreaks, ECMWF Newslett, 146, 1722, https://doi.org/10.21957/s41h7q71, 2016.
Free, M., Sun, B., and Yoo, H. L.: Comparison between total cloud cover in four reanalysis products and cloud measured by visual observations at US weather stations, J. Clim., 29, 2015-2021, 2016.

Gelaro, R., McCarty, W., Suárez, M. J., Todling, R., Molod, A., Takacs, L., Randles, C. A., Darmenov, A., Bosilovich, M. G., Reichle, R., Wargan, K., Coy, L., Cullather, R., Draper, C., Akella, S., Buchard, V., Conaty, A., da Silva, A. M., Gu, W., Kim, G., Koster, R., Lucchesi, R., Merkova, D., Nielsen, J. E., Partyka, G., Pawson, S., Putman, W., Rienecker, M., Schubert, S. D., Sienkiewicz, M., and Zhao, B.: The modern-era retrospective analysis for research and applications, version 2 (MERRA-2), J. Clim., 30, 5419-5454, 2017.

Geleyn, J. F. and Hollingsworth, A.: Economical analytical method for the computation of the interaction between scattering and line absorption of radiation, Beitr. Phys. Atmos., 52, 1-16, 1979.

Han, Q., Rossow, W. B., and Lacis, A. A.: Near-Global Survey of Effective Droplet Radii in Liquid Water Clouds Using ISCCP Data, J. Clim., 7, 465-497, 1994.

Hanley, J. and Caballero, R.: Objective identification and tracking of multicentre cyclones in the ERA-Interim reanalysis dataset, Q. J. Roy. Meteor. Soc., 138, 612-625, https://doi.org/10.1002/qj.948, 2012.

Hawcroft, M., Dacre, H., Forbes, R., Hodges, K., Shaffrey, L., and Stein, T.: Using satellite and reanalysis data to evaluate the representation of latent heating in extratropical cyclones in a climate model, Clim. Dynam., 48, 2255-2278, 2017.

Heidinger, A. K., Foster, M. J., Walther, A., and Zhao, X.: The pathfinder atmospheres-extended AVHRR climate dataset, Bull. Am. Meteorol. Soc., 95, 909-922, 2014.

Jiang, X., Waliser, D. E., Li, J.-L., and Woods, C.: Vertical cloud structures of the boreal summer intraseasonal variability based on CloudSat observations and ERA-interim reanalysis, Clim. Dynam., 36, 2219-2232, https://doi.org/10.1007/s00382010-0853-8, 2011.

Karlsson, K.-G., Anttila, K., Trentmann, J., Stengel, M., Fokke Meirink, J., Devasthale, A., Hanschmann, T., Kothe, S., Jääskeläinen, E., Sedlar, J., Benas, N., van Zadelhoff, G.J., Schlundt, C., Stein, D., Finkensieper, S., Håkansson, N., and Hollmann, R.: CLARA-A2: the second edition of the CM SAF cloud and radiation data record from 34 years of global AVHRR data, Atmos. Chem. Phys., 17, 5809-5828, https://doi.org/10.5194/acp-17-5809-2017, 2017.

Kay, J., Hillman, B., Klein, S., Zhang, Y., Medeiros, B., Pincus, R., Gettelman, A., Eaton, B., Boyle, J., Marchand, R., and Ackerman, T. P.: Exposing global cloud biases in the Community Atmosphere Model (CAM) using satellite observations and their corresponding instrument simulators, J. Clim., 25, 5190-5207, 2012.

Klein, S. A. and Jakob, C.: Validation and Sensitivities of Frontal Clouds Simulated by the ECMWF Model, Mon. Weather Rev., 127, 2514, https://doi.org/10.1175/15200493(1999)127<2514:VASOFC>2.0.CO;2, 1999.

Madonna, E., Wernli, H., Joos, H., and Martius, O.: Warm conveyor belts in the ERA-Interim dataset (1979-2010). Part I: Climatology and potential vorticity evolution, J. Clim., 27, 3-26, 2014.

Martin, G. M., Johnson, D. W., and Spice, A.: The Measurement and Parameterization of Effective Radius of Droplets in Warm Stratocumulus Clouds, J. Atmos. Sci., 51, 1823-1842, 1994. 
McGarragh, G. R., Poulsen, C. A., Thomas, G. E., Povey, A. C., Sus, O., Stapelberg, S., Schlundt, C., Proud, S., Christensen, M. W., Stengel, M., Hollmann, R., and Grainger, R. G.: The Community Cloud retrieval for CLimate (CC4CL) - Part 2: The optimal estimation approach, Atmos. Meas. Tech., 11, 3397-3431, https://doi.org/10.5194/amt-11-3397-2018, 2018.

Mooney, P. A., Mulligan, F. J., and Fealy, R.: Comparison of ERA40, ERA-Interim and NCEP/NCAR reanalysis data with observed surface air temperatures over Ireland, Int. J. Climatol., 31, 545-557, https://doi.org/10.1002/joc.2098, 2011.

Pincus, R., Platnick, S., Ackerman, S. A., Hemler, R. S., and Patrick Hofmann, R. J.: Reconciling Simulated and Observed Views of Clouds: MODIS, ISCCP, and the Limits of Instrument Simulators, J. Clim., 25, 4699-4720, https://doi.org/10.1175/JCLI-D11-00267.1, 2012.

Rossow, W. B. and Schiffer, R. A.: Advances in Understanding Clouds from ISCCP, Bull. Am. Meteorol. Soc., 80, 2261-2288, 1999.

Screen, J. A. and Simmonds, I.: The central role of diminishing sea ice in recent Arctic temperature amplification, Nature, 464, 1334-1337, https://doi.org/10.1038/nature09051, 2010.

Simmons, A. J. and Poli, P.: Arctic warming in ERA-Interim and other analyses, Q. J. Roy. Meteor. Soc., 141, 1147-1162, 2015.

Stapelberg, S., Stengel, M., Karlsson, K.-G., Meirink, J, F., Bojanowski, J., and Hollmann, R.: ESA Cloud_cci Product Validation and Intercomparison Report (PVIR), issue 4, rev. 1, 19 April 2017 Edn., available at: http://www.esa-cloud-cci.org/?q= documentation (last access: 5 December 2018), 2017.

Stengel, M., Stapelberg, S., Sus, O., Schlundt, C., Poulsen, C., Thomas, G., Christensen, M., Carbajal Henken, C., Preusker, R., Fischer, J., Devasthale, A., Willén, U., Karlsson, K.-G., McGarragh, G. R., Proud, S., Povey, A. C., Grainger, R. G., Meirink, J. F., Feofilov, A., Bennartz, R., Bojanowski, J. S., and Hollmann, R.: Cloud property datasets retrieved from AVHRR, MODIS, AATSR and MERIS in the framework of the Cloud_cci project, Earth Syst. Sci. Data, 9, 881-904, https://doi.org/10.5194/essd9-881-2017, 2017a.

Stengel, M., Sus, O., Stapelberg, S., Schlundt, C., Poulsen, C., and Hollmann, R.: ESA Cloud Climate Change Initiative (ESA Cloud_cci) data: Cloud_cci AVHRR-PM L3C/L3U CLD_PRODUCTS v2.0, Deutscher Wetterdienst (DWD), https://doi.org/10.5676/DWD/ESA_Cloud_cci/AVHRRPM/V002, 2017b.

Sun, B., Free, M., Yoo, H. L., Foster, M. J., Heidinger, A., and Karlsson, K.-G.: Variability and trends in US cloud cover: ISCCP, PATMOS-x, and CLARA-A1 compared to homogeneityadjusted weather observations, J. Clim., 28, 4373-4389, 2015.
Sun, Z.: Reply to comments by Greg M. McFarquhar on "Parametrization of effective sizes of cirrus-cloud particles and its verification against observations" (October B, 1999, 125, 3037 3055), Q. J. Roy. Meteor. Soc., 127, 267-271, https://doi.org/10.1002/qj.49712757116, 2001.

Sun, Z. and Rikus, L.: Parametrization of effective sizes of cirrus-cloud particles and its verification against observations, Q. J. Roy. Meteor. Soc., 125, 3037-3055, https://doi.org/10.1002/qj.49712556012, 1999.

Sus, O., Stengel, M., Stapelberg, S., McGarragh, G., Poulsen, C., Povey, A. C., Schlundt, C., Thomas, G., Christensen, M., Proud, S., Jerg, M., Grainger, R., and Hollmann, R.: The Community Cloud retrieval for CLimate (CC4CL) - Part 1: A framework applied to multiple satellite imaging sensors, Atmos. Meas. Tech., 11, 3373-3396, https://doi.org/10.5194/amt11-3373-2018, 2018.

Tiedtke, M.: Representation of Clouds in Large-Scale Models, Mon. Weather Rev., 121, 3040, https://doi.org/10.1175/15200493(1993)121<3040:ROCILS>2.0.CO;2, 1993.

Uppala, S. M., Kållberg, P. W., Simmons, A. J., Andrae, U., Bechtold, V. D. C., Fiorino, M., Gibson, J. K., Haseler, J., Hernandez, A., Kelly, G. A., Li, X., Onogi, K., Saarinen, S., Sokka, N., Allan, R. P., Andersson, E., Arpe, K., Balmaseda, M. A., Beljaars, A. C. M., Berg, L. V. D., Bidlot, J., Bormann, N., Caires, S., Chevallier, F., Dethof, A., Dragosavac, M., Fisher, M., Fuentes, M., Hagemann, S., Hólm, E., Hoskins, B. J., Isaksen, L., Janssen, P. A. E. M., Jenne, R., McNally, A. P., Mahfouf, J.-F., Morcrette, J.-J., Rayner, N. A., Saunders, R. W., Simon, P., Sterl, A., Trenberth, K. E., Untch, A., Vasiljevic, D., Viterbo, P., and Woollen, J.: The ERA-40 re-analysis, Q. J. Roy. Meteor. Soc., 131, 29613012, https://doi.org/10.1256/qj.04.176, 2005.

Waliser, D. E., Li, J.-L. F., Woods, C. P., Austin, R. T., Bacmeister, J., Chern, J., Del Genio, A., Jiang, J. H., Kuang, Z., Meng, H., Minnis, P., Platnick, S., Rossow, W. B., Stephens, G. L., SunMack, S., Tao, W.-K., Tompkins, A. M., Vane, D. G., Walker, C., and Wu, D.: Cloud ice: A climate model challenge with signs and expectations of progress, J. Geophys. Res., 114, D00A21, https://doi.org/10.1029/2008JD010015, 2009.

Webb, M., Senior, C., Bony, S., and Morcrette, J.-J.: Combining ERBE and ISCCP data to assess clouds in the Hadley Centre, ECMWF and LMD atmospheric climate models, Clim. Dynam., 17, 905-922, https://doi.org/10.1007/s003820100157, 2001.

Weidle, F. and Wernli, H.: Comparison of ERA40 cloud top phase with POLDER-1 observations, J. Geophys. Res.-Atmos., 113, D05209, https://doi.org/10.1029/2007JD00923, 2008.

Winker, D. M., Vaughan, M. A., Omar, A., Hu, Y., Powell, K. A., Liu, Z., Hunt, W. H., and Young, S. A.: Overview of the CALIPSO mission and CALIOP data processing algorithms, J. Atmos. Ocean. Technol., 26, 2310-2323, 2009. 